\title{
Production Performance of Koi (Anabus testudineues) with Shing (Heteropnestes fossilis) and Rajpunti (Punteus gonionotus) in Natural Pond Condition
}

Parvez Chowdhury ${ }^{1 *}$, Anuradha Bhadra ${ }^{2}$, AFM Shofiquzzoha ${ }^{2}$

${ }^{1}$ Senior Scientific Officer, Bangladesh Fisheries Research Institute, Headquarters, Mymensingh-2201, Bangladesh

${ }^{2}$ Principal Scientific Officer, Bangladesh Fisheries Research Institute, Headquarters, Mymensingh-2201, Bangladesh

Article History
Received: 07.10 .2020
Accepted: 22.10 .2020
Published: 30.10 .2020
Journal homepage:
http://www.easpublisher.com/easjals/
Quick Response Code

Abstract: The study was carried out in 03 selected farmer's pond at Kaliganj upazilla (sub district) under Lalmonirhat district during June to September 2019 having area of pond 0.30 acre each. Before stocking, ponds were dried and cleaned for weed and unwanted aquatic animals. The dried ponds were treated with limed at the rate of 250 $\mathrm{kg} / \mathrm{ha}$. Five days after liming, water was supplied from shallow tube well to the ponds and filled up to the depth of 1.5 meter. The fry of Koi (A. testudineues) with Shing $(H$. fossilis) and Rajpunti (P. gonionotus) were stocked at the stocking density of 200000; 75,000 and 12500/ha, respectively. After stocking, fish were fed with supplementary feed (30\% crude protein). Fish sampling were done at monthly interval to know the fish growth as well as feed adjustment. After four months rearing, fish were harvested by repeated seine netting. Total bulk weight and number of fish from each pond was recorded. The results showed that Koi reached the harvesting weight ranged of 127$136 \mathrm{~g}$. While harvesting weight range of Shing and Rajpunti were found to be $29-32 \mathrm{~g}$ and 234-250g, respectively. Based on the number of fish harvested at the end of the experiment, survival ranged from 83 to $89 \%$. Total production of Koi (A. testudineues) with Shing (H. fossilis) and Rajpunti (P. gonionotus) as recorded in trial ponds were 23318, 1976 and $2562 \mathrm{~kg} / \mathrm{ha}$, respectively. Total production of fish as recorded in trial ponds were $27856 \mathrm{~kg} / \mathrm{ha}$.

Keywords: Koi, Shing, Rajpunti, Growth Performance, Polyculture, Water quality.

Copyright (9) 2020 The Author(s): This is an open-access article distributed under the terms of the Creative Commons Attribution 4.0 International License (CC BY-NC 4.0) which permits unrestricted use, distribution, and reproduction in any medium for non-commercial use provided the original author and source are credited.

\section{INTRODUCTION}

The fisheries sector plays an important role in the agro-based economy of Bangladesh, through providing food and nutrition, alleviating poverty, creating employment opportunities and earning foreign exchange. Fisheries sector contributes $3.50 \%$ to the national GDP and $25.71 \%$ to the total agricultural GDP. The country's export earnings from this sector are $1.50 \%$ in 2017-18. Fish alone is supplementing about $60 \%$ of animal protein in our daily dietary requirement. About $11 \%$ of the total population is directly or indirectly employed in fisheries sector [1]. Fisheries of Bangladesh have immense prospects and scope of development.

Pond aquaculture in Bangladesh is expanding very fast. Currently aquaculture production accounts for about one third of the total fish production in Bangladesh. To increase the production of fish, species selection is very important. Pond aquaculture in Bangladesh is expanding very fast presently. According to $\mathrm{FAO}$ report, Bangladesh ranked $3^{\text {rd }}$ in inland open water capture production and $5^{\text {th }}$ in world aquaculture production [1]. To increase the suitable indigenous fish species production, species selection is very important. Polyculture is a popular way to raise fish production. From the historical facts, this system was started in China [2, 3]. Polyculture is the system in which fast growing compatible species of different feeding habits are stocked in different proportions in the same pond [4], which has been practicing from the very beginning of the fish culture in China and in India. Modern fish culture means improvement of cultural practices through adopting different measures such as proper doses of fertilizer application, maintenance of physicochemical factors, utilizing the total pond area selecting the fishes those graze on different layers of the pond, regular feeding, disease prevention and various control measures. These culture techniques are partially followed in this country. It is perhaps the right time to think as to how the fish production could be increased at minimum time, labor and money. 
Koi is an integral component of subsistence fisheries for thousands of years but has gained popularity in very recent years. Shing and Rajpunti are better performing species in the pond aquaculture system of Bangladesh. These two fishes are great favorite to consumers because of its mouth-watering taste and therefore have a great demand and high price in the fish market. Though these two species have been reported quite favorable under standard conditions of carp farming, their culture technique with carps in polyculture system is still under developed. This trial was designed to evaluate the production performances of Koi (Anabus testudineues) with Shing (Heteropnestes fossilis) and Rajpunti (Punteus gonionotus) in polyculture management at natural pond condition.

\section{MATERIAL AND METHODS Experimental Ponds}

Three ponds of 3 farmers at Kaliganj upazilla (sub-district) were used under Lalmonirhat district June to September 2019. The average of pond area was 0.35 acre each.

\section{Preparation of pond}

Selected ponds were free from predatory animals, unwanted fishes and aquatic higher vegetation. Flexible plastic pipes were used for water supply from the deep tube-well. The embankment was well protected and covered with grass. Prior to commencing the experiment, rotenone $(12.50 \mathrm{~kg} / \mathrm{ha})$ was applied to eradicate predators and small fish. Then ponds were treated with lime at the rate of $250 \mathrm{~kg} / \mathrm{ha}$.

\section{Source of Fingerlings}

The fingerlings of Rajpunti were used in this experiment were produced in Freshwater sub-station, Bangladesh Fisheries Research Institute, Nilphamari. Another species, Koi and Shing were collected from the Privet Fish Hatchery, Adamdighi, Bogura district. The initial weight of Koi, Shing and Rajpunti were $1 \mathrm{~g}, 2.2 \mathrm{~g}$ and $2.0 \mathrm{~g}$, respectively.

\section{Stocking of fish}

The fry of Koi (A. testudineues) with Shing ( $H$. fossilis) and Rajpunti (P. gonionotus) were stocked at the stocking density of 200000; 75,000 and 12500/ha, respectively.

\section{Feed and Feeding Management}

The fingerlings of Koi, Shing and Rajpunti were stocked on 01 june 2019. After stocking, in all treatments, a $30 \%$ protein containing pelleted feed were applied at the rate of $12-3 \%$ of estimated fish biomass twice daily at $7.0 \mathrm{pm}$ and $8.0 \mathrm{am}$. The fingerlings were fed at the rate of $12 \%$ of their body weight for the first two weeks and it was reduced to $3 \%$ on the subsequent months. During the culture trail, lime and salt were applied in all the ponds fortnightly interval at the rate of 50 and $100 \mathrm{~kg} / \mathrm{ha}$, respectively.

\section{Fish Sampling}

Twenty fish of each species from each pond were caught at each monthly sampling day using a seine net. Individual weight of each species was measured by using a portable balance (Tanita, Japan; accuracy 1g). After weighted, all fishes were returned into the ponds after sampling.

\section{Study of water quality parameters}

Transparency (cm): Water transparency of the experimental ponds was measured by a Secchi-disk.

Temperature $\left({ }^{\circ} \mathbf{C}\right)$ : Water temperature data were collected from the ponds by using portable thermometer.

Dissolved oxygen (mg/L): Dissolved oxygen of water was measured by portable digital dissolved oxygen (DO) meter (model: DO5509, Lutron, made in Taiwan).

pH (Hydrogen-ion concentration): $\mathrm{pH}$ was determined by a portable digital $\mathrm{pH}$ meter (Hanna Instruments, Italy, model-H 196107).

Free carbon dioxide (mg/L): For determining free carbon dioxide of water, samples were collected in 250 $\mathrm{ml}$ black plastic bottles and titrated with $0.022 \mathrm{~N}$ sodium hydroxide solution using phenolphthalein as indicator.

Total alkalinity (mg/L): To determine total alkalinity, samples were collected in $250 \mathrm{ml}$ black plastic bottles and total alkalinity of water samples was determined by titrimentric method using methyl orange indicator.

\section{Harvesting}

At the end of the experiment, the fishes were harvested, first by seine netting and then by draining out of the ponds. The harvested fishes were counted and weight was recorded to find out the survival rate and production.

\section{Data Analysis}

Data were analyzed using the statistical package, Stat Graphics Version 7. ANOVA was performed on all the dependent variables to find out whether treatments had any significant difference on growth.

\section{RESULTS}

\section{Water quality parameters}

Environmental parameters exert an immense influence on the maintenance of a healthy aquatic environment and production of natural food organisms. Growth, feed efficiency and feed consumption of fish are normally governed by a few environmental factors.

Mean values of five months data of each of the parameter are presented in Table- 1 . 
Table-1: Water quality parameters of different ponds

\begin{tabular}{|l|l|l|l|}
\hline \multirow{2}{*}{ Parameter } & \multicolumn{3}{|l|}{ Kaliganj Upazila } \\
\cline { 2 - 4 } & Pond-1 & Pond-2 & Pond-3 \\
\hline Temperature $\left({ }^{\circ} \mathrm{C}\right)$ & $35.05 \pm 4.59^{\mathrm{a}}$ & $35.88 \pm 0.04^{\mathrm{a}}$ & $36.50 \pm 3.06^{\mathrm{a}}$ \\
\hline Transparency $(\mathrm{cm})$ & $29.10 \pm 5.19^{\mathrm{a}}$ & $31.19 \pm 0.55^{\mathrm{a}}$ & $35.40 \pm 5.50^{\mathrm{b}}$ \\
\hline Dissolved oxygen $(\mathrm{mg} / \mathrm{L})$ & $5.04 \pm 2.57^{\mathrm{a}}$ & $5.17 \pm 1.13^{\mathrm{b}}$ & $5.23 \pm 0.25^{\mathrm{b}}$ \\
\hline $\mathrm{pH}$ & $7.13 \pm 1.91^{\mathrm{a}}$ & $7.99 \pm 0.93^{\mathrm{b}}$ & $7.67 \pm 2.58^{\mathrm{b}}$ \\
\hline Total Alkalinity $(\mathrm{mg} / \mathrm{L})$ & $133.27 \pm 13.13^{\mathrm{a}}$ & $147.31 \pm 11.77^{\mathrm{b}}$ & $154.5 \pm 30.26^{\mathrm{b}}$ \\
\hline
\end{tabular}

*Figures in the same row having the same superscripts are not significantly different $(\mathrm{P}>0.05)$

\section{Growth and production performances}

For reporting the growth performance, only weight was considered along with other yield parameters. Details of stocking, growth and production performances in different treatments are presented in Table-2.

Table-2: Growth and production performances of the fish in different ponds

\begin{tabular}{|c|c|c|c|c|c|c|}
\hline Fish sp. & $\begin{array}{l}\text { Initial Wt. } \\
\text { (g) }\end{array}$ & $\begin{array}{l}\text { Stocking } \\
\text { density/ha }\end{array}$ & $\begin{array}{l}\text { Harvesting } \\
\text { Wt. (g) }\end{array}$ & $\begin{array}{l}\text { Survival } \\
(\%)\end{array}$ & $\begin{array}{l}\text { Total Species wise } \\
\text { Production (kg/ha) }\end{array}$ & $\begin{array}{l}\text { Total Production } \\
(\mathrm{kg} / \mathrm{ha})\end{array}$ \\
\hline Koi & $1.0 \pm 0.32$ & 200000 & $131 \pm 8.43^{\mathrm{a}}$ & 89 & $23318 \pm 16.01$ & \\
\hline Shing & 1.24 & 75,000 & $31=$ & 85 & 36.03 & \\
\hline Rajpunti & $4.40 \pm 2.32$ & 12500 & $247 \pm 3.35^{\mathrm{a}}$ & 83 & $2562 \pm 24.11$ & $27856 \pm 14.21$ \\
\hline
\end{tabular}

\section{DISCUSSION}

The water temperature recorded during the study period was more or less similar in different ponds under three treatments. Temperature varied from 35.02 to 36.55 with mean values of $35.05 \pm 4.59,35.88 \pm 0.04$, and $36.50 \pm 3.06{ }^{\circ} \mathrm{C}$ in pond-1, 2 and 3 , respectively (Table-1). There were no significant differences among the treatments when ANOVA was performed $(\mathrm{P}>0.05)$. Paul [5] recorded temperature ranged from 25 to $35^{\circ} \mathrm{C}$ is suitable for fish culture. Ali [6] stated that water temperature of ponds remain 20.20 to $36.50{ }^{\circ} \mathrm{C}$ which was favorable to fish culture. Kohinoor et al., [7] stated that water temperature of ponds remain 28.70 to 28.81 ${ }^{\circ} \mathrm{C}$ which was favorable to koi, shing and tilapia polyculture. In the present experiment water temperature was favorable for fish culture.

Water transparency values of different ponds under the treatments showed variations on different sampling dates. The transparency values ranged from 27 to $38 \mathrm{~cm}$ with mean values of transparency were found to be $29.10 \pm 5.19,31.19 \pm 0.55$, and $35.40 \pm 5.50 \mathrm{~cm}$ in pond-1, 2 and 3, respectively (Table-1). Significant differences among the treatments were observed when ANOVA was performed $(\mathrm{P}<0.05)$. Transparency values increased with increasing the stocking density of Pabda due to lower abundance of phytoplankton, indicating that Pabda grazed more on plankton. Rahman [8] stated that the transparency of productive waterbodies should be $40 \mathrm{~cm}$ or less (turbidity resulting from plankton). Chowdhury et al., [9] recorded transparency values ranging from 17 to $34 \mathrm{~cm}$ in tilapia monoculture. Kohinoor et al., [7] recorded transparency values ranging from 26 to $36 \mathrm{~cm}$ in koi, shing and tilapia polyculture. The water transparency values of these ponds were within productive range in the present experiment.
The values of dissolved oxygen were found to range from 5.01 to $5.24 \mathrm{mg} / \mathrm{L}$ with mean values of mean values of pond-1, 2 and 3 were 5.04 \pm 2.57 , $5.17 \pm 1.13$ and $5.23 \pm 0.25 \mathrm{mg} / \mathrm{L}$, respectively (Table-1). The water transparency values of these ponds were within productive range in the present experiment. Mazid [10], Sharmin et al., [11], Majumder [12], Sarker [13] found more or less similar results. In the present experiment the mean dissolved oxygen values were within suitable range.

During the study period, the $\mathrm{pH}$ values of pond water under different treatments were found to be alkaline. The values of dissolved oxygen were found to range from 7.11 to $8.13 \mathrm{mg} / \mathrm{L}$ with mean values of mean values of pond-1, 2 and 3 were $7.13 \pm 1.91$, $7.99 \pm 0.93$ and $7.67 \pm 2.58 \mathrm{mg} / \mathrm{L}$, respectively (Table-1). Different authors have reported a wide variations in $\mathrm{pH}$ from 6.7 to 7.2 [14]; 6.7 to 8.3 [15], 7.18 to 7.24 [16] and 7.78 to 7.89 [7] in fertilized fish ponds and found to be productive. The values of $\mathrm{pH}$ recoded in the present experiment are well within above reported ranges, indicating the productive nature of the ponds.

The total alkalinity values of the pond water under different treatments were found to be productive level. The values of total alkalinity were found to range from 131 to $155 \mathrm{mg} / \mathrm{L}$ with mean values of pond-1, 2 and 3 were $133.27 \pm 13.13,147.31 \pm 11.77$ and $154.5 \pm 30.26 \mathrm{mg} / \mathrm{L}$, respectively. Significant variations $(\mathrm{P}>0.05)$ were observed among the treatments. Majumder et al., [12] recorded total alkalinity values ranging from 164 to $167 \mathrm{mg} / \mathrm{L}$. Kohinoor et al., [7] stated that the total alkalinity of medium productive water ranged from 135-147 mg/L. 
The average final weights of Koi, Shing and Rajputi were $131 \pm 8.43,31 \pm 5.03 .2$ and $247 \pm 3.35 \mathrm{~g}$, in the experimental ponds. The mean values of survival rates in pond-1, 2 and 3 were 89,85 and $83 \%$, respectively. Sultan [17] obtained survival rates $93.75 \%, 91.88 \%, 86.88 \%$ under treatment-1, treatment2 , and under treatment- 3 in polyculture of tilapia, rui, catla and mrigal. After four months rearing, the production of Koi, Shing and Rajputi obtained were $23318 \pm 16.01, \quad 1976 \pm 36.03$ and $2562 \pm 24.11 \mathrm{~kg} / \mathrm{ha}$, respectively (Table-2). The total production was 27856 $\mathrm{kg} / \mathrm{ha}$. Kohinoor et al., [18] recorded an average production from semi-intensive culture of Koi, Shing and tilapia under treatment-1, treatment-2, and under treatment-3 in four months culture period as 17995 , 16805 and $17310 \mathrm{~kg} / \mathrm{ha}$, respectively.

\section{ACKNOWLEDGEMENTS}

This experiment conducted through the project "Field Validation of Selected High Valued Fish Culture Technologies for Maximizing Production (2018-19)" of Bangladesh Fisheries Research Institute, Mymensingh.

\section{REFERENCES}

1. DoF. (2019). Fisheries Yearbook of Bangladesh. Department of Fisheries (DoF), Ramna, Dhaka.

2. Ling, S. W. (1974). Aquaculture in south East Asia, University of Washington press. Seattle. 108.

3. Chang, W. Y. B. (1987). Fish culture in China. Fisheries, 12, 23.

4. Jhingram, V. G. (1975). Aquaculture lecture, Summer Int. Intensive fresh water fish culture, Cuttack, Organized by Centre, Inland Fish. Res. Inst., Braackpore (ICAR), India. pp. 12.

5. Paul, S. (1998). Comparison between carp polyclture system with silver carp, (Hypophthalmichthys molitrix) and with small indigenous fish mola, (Amblypharyngodon mola). MS Thesis, Department of Fisheries Management, Bangladesh Agricultural University, Mymensingh. 85 .

6. Ali, M. H. (1998). The potential of periphytonbased monoculture of a major carp,calibaush Labeo calbasu (Hamilton), MS Thesis, Department of Fisheries Management, Bangladesh Agricultural University, Mymensingh, Bangladesh, 37.

7. Kohinoor, A. H. M., Rahman, M. M., \& Hussain, M. G. (2017). Evaluation of production performances of Koi (A. testudineus), with Shing (H. fossilis) and GIF Tilapia (O. niloticus) in semiintensive culture management, 5(1):446-451.
8. Rahman, M. S. (1992). Water Quality Management in Aquaculture. BRAC Prokashana, Dhaka. 84.

9. Chowdhury, P., Hossain, M. Z., Raushon, N. A., \& Rahman, M. S. (2018). Effects of different amounts of organic fertilizers on growth and production of tilapia in monoculture. Int J Agril Res Innov Tech. 18(2):24-31.

10. Mazid, M. A. (2009). Impacts of fish population density in the growth and production of carps in polyculture system. MS Thesis, Department of Fisheries Management, Bangladesh Agricultural University, Mymensingh, Bangladesh, 56.

11. Sharmin, F., Rahman, M. S., Shahjahan, M., \& Chowdhury, P. (2019). Study of growth and productions of tilapia (Oreochromis niloticus) on different population densities in monoculture. Int $J$ Agril Res Innov Tech. 9(2):76-83.

12. Majumder, T. H., Chowdhury, P., Shahjahan, M., \& Rahamn M. S. (2017). Effects of population density on growth and production of tilapia in monoculture. MS Thesis, Department of Fisheries Management, Bangladesh Agricultural University, Mymensingh, Bangladesh, 34.

13. Sarker, M. K. H. (2007). Impacts of duckweed powder as an ingredient of feed on production ofTilapia (Oreochromis niloticus). MS Thesis, Department of Fisheries Management, Bangladesh Agricultural University, Mymensingh. 87.

14. Ahmed, K. (1993). The effect of feed and fertilizers on carp polyculture in ponds. $\mathrm{Ph} . \mathrm{D}$. dissertation, Department of Zoology, Dhaka University. 162.

15. Hossain, M. A., Rahmatullah, S. M., Islam, M. S., Kabir, A. K. M. A., Islam, M. S., \& Dewan, S. (1997). Impact of chapila (Gudusia chapra Ham.) on growth of carps in polyculture. Bangladesh $J$ Fish Res, 1(2):19-23.

16. Kohinoor, A. H. M., Hossain, M. A., \& Hussain, M. G. (1997). Semi-intensive culture and production cost of pabda (Ompok pabda) with rajpunti (Puntius gonionotus) and mirror carp (Cyprinus carpio var. specularis) in mini ponds. Bangladesh J Zool. 254(2):129-133.

17. Sultan, R., Kohinoor, A. H. M., Islam, M. S., \& Hussain M. G. (1997). Comparative-studies on growth of fry of GIFT and existing strain of Nile Tilapia (Oreochromis niloticus). Bangladesh Journal of Fisheries Research, 1:25-30.

18. Kohinoor, A. H. M., Rahman, M. M., Islam, M. S., \& Mahmud, Y. (2016). Growth and production performance of climbing perch Thai Koi and Vietnamese Koi Strain (Anabas testudineus) in Bangladesh. International Journal of Fisheries and Aquatic Studies, 4(1), 354-357. 